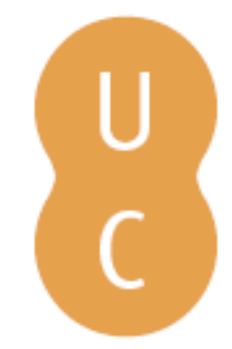

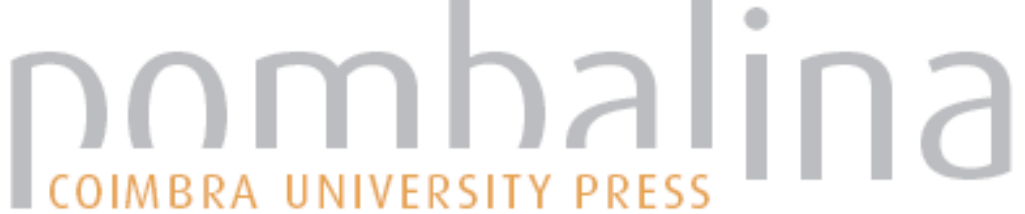

Instant foam technology to improve aerial firefighting effectiveness

Autor(es): Restas, Agoston

Publicado por: Imprensa da Universidade de Coimbra

URL

persistente: URI:http://hdl.handle.net/10316.2/34267

DOI: $\quad$ DOI:http://dx.doi.org/10.14195/978-989-26-0884-6_156

Accessed : $\quad$ 26-Apr-2023 12:25:22

A navegação consulta e descarregamento dos títulos inseridos nas Bibliotecas Digitais UC Digitalis, UC Pombalina e UC Impactum, pressupõem a aceitação plena e sem reservas dos Termos e Condições de Uso destas Bibliotecas Digitais, disponíveis em https://digitalis.uc.pt/pt-pt/termos.

Conforme exposto nos referidos Termos e Condições de Uso, o descarregamento de títulos de acesso restrito requer uma licença válida de autorização devendo o utilizador aceder ao(s) documento(s) a partir de um endereço de IP da instituição detentora da supramencionada licença.

Ao utilizador é apenas permitido o descarregamento para uso pessoal, pelo que o emprego do(s) título(s) descarregado(s) para outro fim, designadamente comercial, carece de autorização do respetivo autor ou editor da obra.

Na medida em que todas as obras da UC Digitalis se encontram protegidas pelo Código do Direito de Autor e Direitos Conexos e demais legislação aplicável, toda a cópia, parcial ou total, deste documento, nos casos em que é legalmente admitida, deverá conter ou fazer-se acompanhar por este aviso.

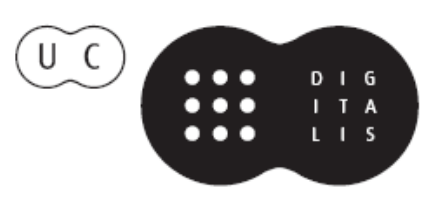




\section{ADVANCES IN}

Forest Fire

\section{RESEARCH}

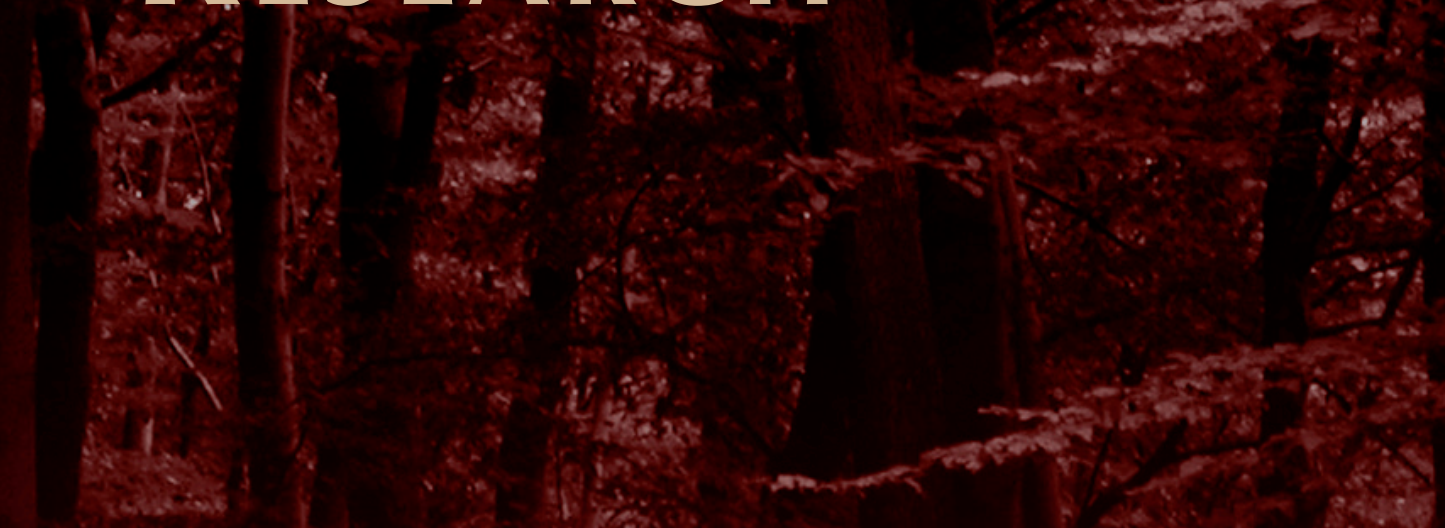

\section{DOMINGOS XAVIER VIEGAS}

\section{EDITOR}




\title{
Instant foam technology to improve aerial firefighting effectiveness
}

Agoston Restas

\author{
National University of Public Service, Budapest, Hungary, Restas.Agoston@uni-nke.hu
}

\begin{abstract}
Introduction: This paper describes a new technology, making the process of aerial firefighting more effective. Instant foam technology based on adopted patent, called Foam Fatal, used by petrol industry. Methodology: Before starting the project prepared a study which is focused the economic efficiency of aerial firefighting. This study says that the effectiveness of aerial firefighting using just pure water is very limited but there are possibilities for extending this effectiveness. Instant foam technology can use any traditional foam solution in a special tank installed on board and this liquid emitted in the required place by pressure. Whit this process the quality of the created foam become very homogeneous and some feature also can be modified during the process. Results and discussion: No doubt, in the market there are already some special water tanks, even with pressured systems, however the results comparing the extended efficiency of the instant foam technology to the others is notable. Moreover, instant foam technology is even cost effective, making the process of aerial firefighting real effective.
\end{abstract}

Keywords: instant foam, homogenous foam structure, effective fire suppression, aerial firefighting

\section{Introduction}

One effect of global climate change is the increased risk of forest and vegetation fire and the higher intensity of these fires, thus the resulting damage is more severe. The application of aircraft and helicopters in large-scale forest fires is a globally widespread practice. They can transport great amount of extinguishers, mainly water to places which road vehicles cannot reach. However, even this amount is often not enough. The author aims to present a potential new method of increasing the effectiveness of extinguishers.

The new technology is based on a Hungarian patent ${ }^{1}$, whose goal is to effectively extinguish extensive fires of containers used in petroleum industry with instant foam. The adaptation of this technology in forest fire fighting has raised interest. Thus, the author wishes to introduce and develop this technology as an innovation in the market of forest and aerial fire fighting with the consent of the owner of the patent. The article describes the author's related research, result and the adaptation of the technology.

\section{Possibilities and barriers of water extinguishing}

\subsection{Theoretical backgrounds of water extinguishing}

The most common extinguishing material used in fighting against forest fire is water. Unfortunately its maximum volume is objectively limited on surface (Csontos et al., 2007). Twigs of an average age ( $40-80$ years) pine forest is able to hold about $4-5$ litres water per square meter. These amounts of water makes the surface wet but using more amounts will drop to ground and be out of the burning zone without any effect. All resources we used for carrying this water can be evaluated as a waste and useless expenditure.

\footnotetext{
${ }^{1}$ Foam Fatal technology; http://foamfatale.com/
} 
Based on specific heat capacity of 1 litre of $20 \mathrm{C}^{0}$ water $^{1}\left(4.2 \mathrm{~kJ} / \mathrm{kgC}^{0} \times 80 \mathrm{C}^{0}=336 \mathrm{~kJ} / \mathrm{kg}\right)$ and counts with its evaporation heat ${ }^{2}(2684 \mathrm{~kJ} / \mathrm{kg})$ the cooling capacity is $3020 \mathrm{~kJ} / \mathrm{kg}$. Based on the $51 / \mathrm{m}^{2}$ maximum weight of water on the surface its cooling capability without waste is $15100 \mathrm{~kJ}$.

The volume of the biomass per square meter at a mature forest obviously can move at a wide scale. Based on the author's experience its volume which can catch fire during burn is about $6-10 \mathrm{~kg} / \mathrm{m}^{2}$. Based on Nagy (2007) its heat of combustion $(\approx 18500 \mathrm{~kJ} / \mathrm{kg})$ is about $111000-185000 \mathrm{~kJ}$.

Water content of the biomass is taken as $70 \%$ (Nagy, 2007) during an extreme weather condition perhaps less. Based on the above the rate of water of a $6-10 \mathrm{~kg}$ bulk is about $4.2-7 \mathrm{~kg}$ that has to be evaporated by its own combustion heat. Cooling capacity of the above amount of water is between $12684-21140 \mathrm{~kJ}$.

The heat combustion of the part of pine bulk, can be count during burn is (111000-185000 kJ) much higher than the common cooling capacity of water content of the bulk (12684-21140 kJ) and the maximum water amount on its surface $(15100 \mathrm{~kJ})$. It means with water the suppression of a developed fire is objectively not possible. The difference between the combustion heat and the cooling capacity is at the lower threshold 4 times, at the upper level 5 times higher for the combustion heat! Based on the above the practice can be demonstrated, above that fire intensity where $5 \mathrm{~kg} / \mathrm{m}^{2}$ water is not enough for suppression, the active, fighting tactics is avoided with pure water even in case of aerial firefighting (Georges, 1975; Hardy, 1985).

\subsection{Losses of aerial firefighting}

\section{Losses during transportation}

In case of helicopters there are significant water losses during transportation. Bucket has no cap therefore there is a friction between the water surface and moving air. This effect, like the Bernoulli principle, takes lots of water out from the bucket and it looks like an evaporation cloud above-after the bucket. This loss depends mainly on the speed of transportation and the carrying distance. The other type of losses is caused by mechanical effect, mainly immediately after the upload but also during the whole transportation route. Water swing in the bucket and clashing to the wall lots of water will splash out from the bucket. Based on some observers above losses can be over $30 \%$, in extreme conditions even $50 \%$ (Jambrik, 2007, Imreh at al., 2009).
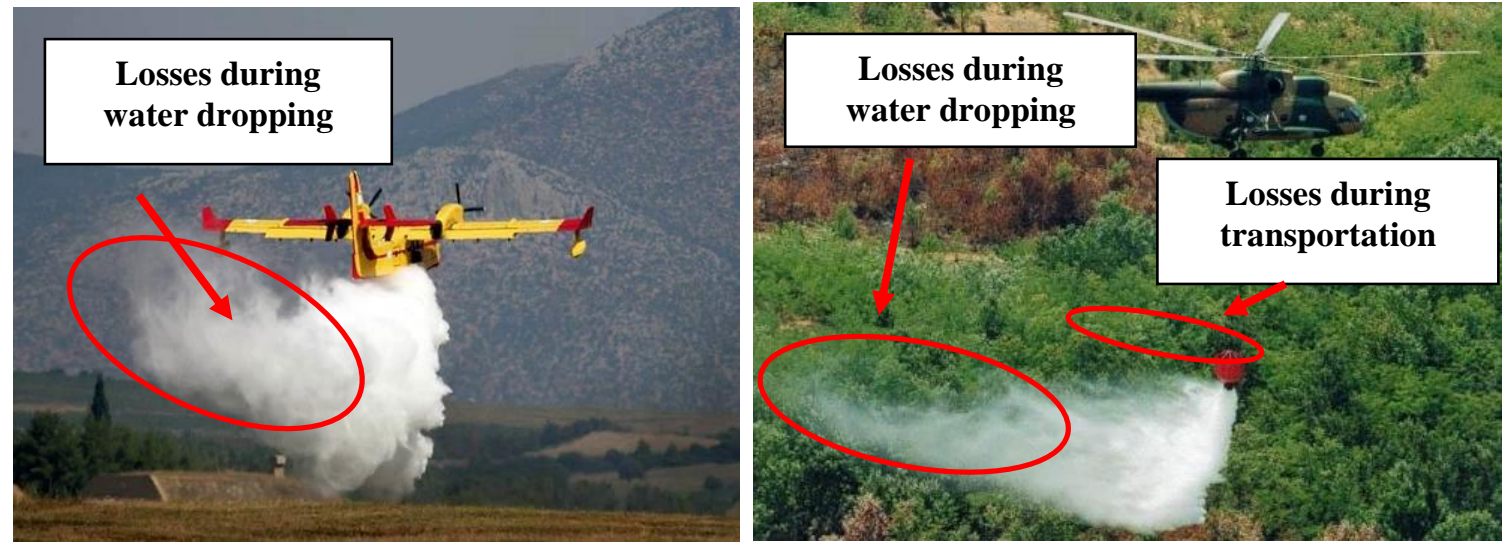

Figure 1. Losses of aerial firefighting

\footnotetext{
${ }^{1}$ Specific heat capacity (c) of water is: $4.2 \mathrm{~kJ} / \mathrm{kgC}^{0}$; Formula is: $\mathrm{E}_{\mathrm{c}}=\mathrm{c} \mathrm{m} \mathrm{dT}=1680 \mathrm{~kJ}$

${ }^{2}$ Evaporation heat (p) is: $2684 \mathrm{~kJ} / \mathrm{kg}$; Formula is: $E_{\mathrm{p}}=\mathrm{p} \mathrm{m}$
} 


\section{Losses during water dropping}

After opening the valve water decomposes to drops creating water cloud. Usually it is generated by the strong airflow spontaneously; however there can be generated also some technical means. Raising the speed of the fly the rate of spray will also rise. Unfortunately, the very small water drops can leave the requested area without significant help in the suppression or the rate at the surface is below the effectiveness threshold. Some observations say this loss can be about 5-10\% (Delforge, 2001).

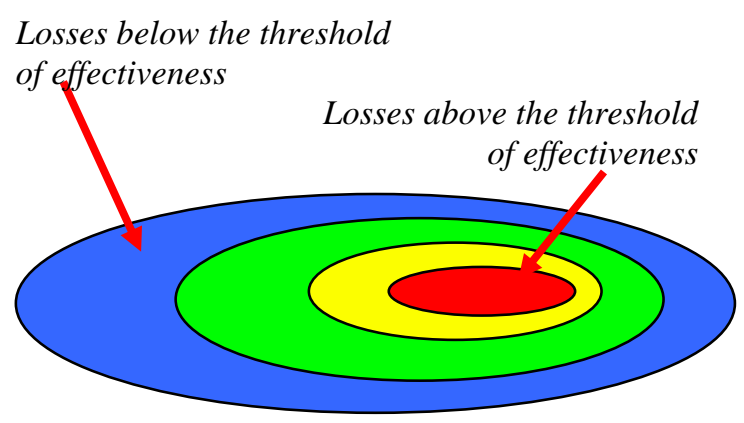

Figure 2. Losses above and below the threshold of effectiveness

\section{Losses above and below the thresholds of effectiveness}

For the effective suppression we must ensure there is enough water quantity per square meter. If this water quantity is below a threshold there is no suppression effect of water; it means this volume is lost. All resources we spent for this volume to be carried to the fire front is a useless expenditure. Since the footprint of water dropping is never homogenous, from the middle to the edge less and less, unfortunately this loss can't be avoided. Even if experts keep this minimum threshold volume different ${ }^{1}$ it is between $0.2-0.8 \mathrm{l} / \mathrm{m}^{2}$.

In the middle of the footprint of dropping water the water quantity can be higher than it is required. Bulk can hold no more than $5 \mathrm{l} / \mathrm{m}^{2}$ water on leaves. Above this quantity water drip to the ground and there is no effect for crown fire; it means this volume is loss. All resources we spent on this volume to be carried to the fire front is also a useless expenditure. The rate of losses above and below the thresholds of effectiveness is about $10-20 \%$.

\section{Loss of evaporation}

If water dropping is not directly to fire front but some meter before it making a wetting zone a significant evaporation loss can be noticed. It is caused by the huge surface (wetting leaves), small water drops and high temperature. It takes time the fire front moving ahead and reach the wetting zone. Depending on the distance and the speed of fire propagation the time interval - fire front reaches the wetting zone - can be significant and during this time loss of evaporation can be remarkable; it means evaporated volume is loss which can be more than $25 \%$ (Delforge, 2001).

\section{Other losses}

There are other losses, like targeting, navigation or coordination losses, however these are almost the same technologies, therefore different analysis is not necessary.

Based on the above, author counts with the average rate of losses $25 \%$ in case of on-board installed tanks and $50 \%$ in case of buckets.

\footnotetext{
${ }^{1}$ It depends on literatures, those are differences, e.g. $0.51 / \mathrm{m}^{2}$ (Szabo, 1994); $0.81 / \mathrm{m}^{2}$ (Delforge, 2001)
} 


\subsection{Possibilities enhancing water capabilities}

Regarding the above problems experts search different ways to enhance water capabilities. It means different applications, like using retardant, gel, foam agent, specially developed explosion extinguishers ${ }^{1}$ or even developing new kind of extinguisher materials ${ }^{2}$.

\section{Technical solutions}

Based on the above analysis, it can be seen one part of losses are not avoidable, other part - mainly in case of helicopter - it relates to using bucket. This latest one - because of the Venturi effect - can cause even more than $30 \%$ losses of transport capacity. This loss can eliminate in case of using tank, therefore different types of its appeared like on-board ${ }^{3}$ or to belly installed tank ${ }^{4}$.

\section{Knock out effect}

In many cases practice uses the kinetic energy of dropped water to suppress fire, so called „,knock out” effect. In this case aircraft pilot drops water directly to the fire front and besides the cooling effect the kinetic energy of water mass also helps to suppress the fire; it breaks the chain reaction of burning process tearing down the flames. This method gladly used by aerial firefighting. An aircraft with flight speed of $180 \mathrm{~km} / \mathrm{h}$ and altitude of $20 \mathrm{~m}$ generates kinetic ${ }^{5}$ and potential ${ }^{6}$ energy of $1 \mathrm{~kg}$ water about sum $1.45 \mathrm{~kJ}$. The problem is that even if this method many times effective way to suppress - "knock out" - a short section of the fire front but the used kinetic energy of $1 \mathrm{~kg}$ water is much less than either the specific heat capacity or the evaporation heat capacity of water. Economically author evaluates this method waste because the extinguishing potential of the carried water is much higher than just the kinetic energy. (Naturally during knock out effect besides kinetic energy the cooling effect has also an important role. Its rate requires more analysis.)

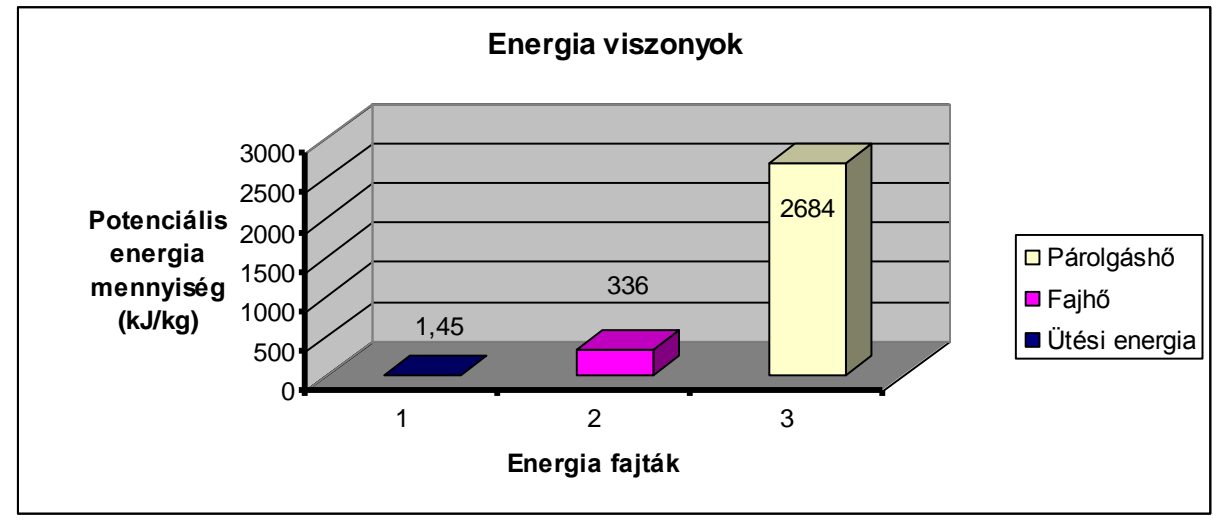

Figure 3. Kinetic energy (1 / blue), heat capacity (2 / purple) and evaporation heat (3 / yellow) of dropped unit water. Source: R-Fire Ltd. I4F technology Manuscript

\footnotetext{
${ }^{1}$ e.g. Beaextin S.L., http://www.lucka.be/brandbeveiliging/extras/efp-fire-suffication.pdf

${ }^{2}$ Special salt mix; 2 years research project, BASF presentation, Aerial Fire Fighting Conference, 2008, Athens, Greece

3 e.g. Coulson C-130 Next Gen Airtanker: http://fireaviation.com/2013/07/12/removing-coulsons-c-130-tank/

${ }^{4}$ e.g. Simplex: http://www.simplex.aero/fire-attack/

${ }^{5} E_{\text {kinetic }}=1 / 2 \mathrm{~m} \mathrm{v}$; in the above example $1250 \mathrm{~J}$

${ }^{6} \mathrm{E}_{\text {potential }}=\mathrm{mgh}$; in the above example $200 \mathrm{~J}$
} 


\section{Retardants}

There are also other solutions to enhance water capability which are based on different agent additions. One of these is using retardant that makes water drops more homogeneous causing less waste and there are not just cooling but also chemical based effects. Author focused on energy balance and potential suppression capability of extinguishing materials therefore the water equivalent of chemical based effects of retardant is missing however the value of its obviously can be very interesting and also planned to be one of author's next research topic.

\section{Foam}

Besides the retardant there is another method to enhance water suppression capability that is using agents to generate foams from its solution. In case of foam beside the cooling effect there can be also extra extinguishing effects. One of them is that agent reduces water's surface tension therefore the pine bulk can be covered by more homogenous foam drained solution. Other kind of the effect is that the structure of foam creates an isolation effect that can protect leaves from heat radiation. Based on this extra extinguishing effect fire propagation can reduce significantly and there is no enough radiation heat to keep chain reaction of flames alive. Based on authors study there is a way to optimize the isolation effect of foam and expand its capability to that dimension where pure water objectively can't be effective.

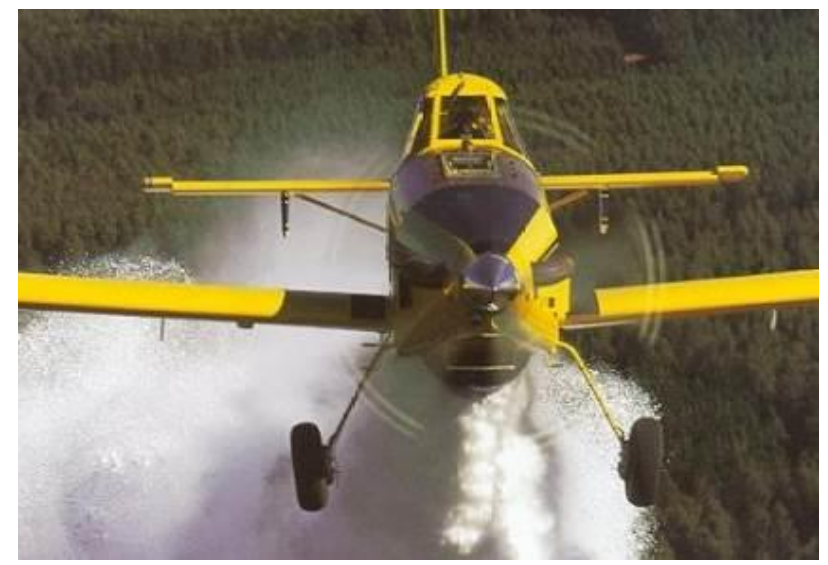

Figure 4. Aerial firefighting with using foam traditionally

Opposite to generate a foam structure there can be another aim to use foam agent. As mentioned above minimal rate of foam agent mixed to water can reduce the surface tension. In this case the rate of agent can remain below $1 \%$ however this amount is enough to enhance the water effectiveness. Before fire it means water can cover pine bulk homogenous, after fire water can wet the glowed or sooty surface more effectively.

In case of foam using the evaporation loss is also less. Other side depending mainly on the type of foam agent the water draining from foam structure is natural phenomenon. Unfortunately this phenomenon reduces the foam effectiveness however with a good firefighting tactic - optimizing the distance between the fire front and foamed strip - it can minimize, that means a minimum ,waiting time" fire front reaches the foamed zone. 

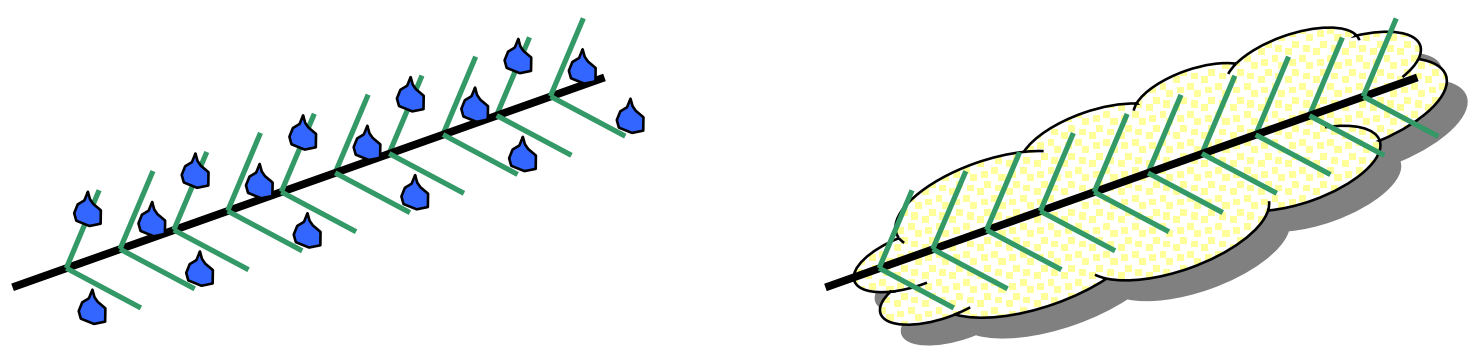

Figure 5. Water drops and foam blanket on pine bulk. Structural graphic

Based on the above, next part uses practical and theoretical investigations focusing on the possibilities of raising foam effectiveness.

\section{Problems extinguishing with foam}

In common cases using modern foam are believed to be very effective. Firstly, as addition of agent it is able to reduce the surface tension resulting better wetting effect, the other one is that with different equipment we are able to generate a foam structure. This structure depends on many conditions however in most cases it generates mechanically by the collision of solution and equipment dropping solution to air.

In case of aerial firefighting we can also face to use foam however there are some barriers of effective use. Dropping solution from the tank it strikes a grid or net to mix with air and generate foam but in most cases solution collide with air spontaneously (Figure 4), resulted foam. In case of bucket a special „foam sack" attached to water sack and its net mix air and solution generating inhomogeneous foam structure.

The effectiveness of foam depends on many conditions, like the mixing rate, expanditure rate, speed of solution dropping (flight speed), altitude and also the homogeneity.

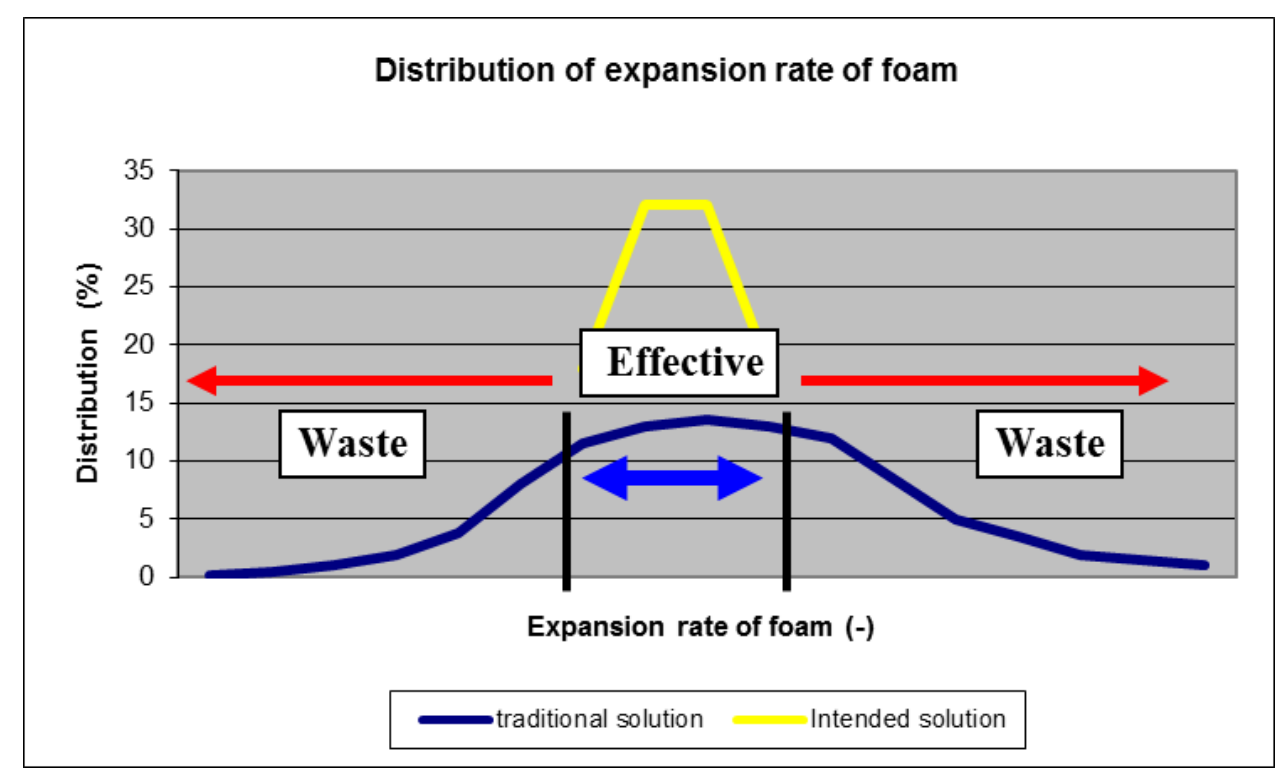

Figure 6. Foam bulb's distribution of traditional and new technologies depending on expansion rate

Foams with different structure and feature have different behaviour. Foams with large expanditure rate can be driven from the required place by the rotor wind of helicopter or by the fire caused convection 
and there is no effect to suppress fire. Foams habitant on crown depends on its dense; light dense foam remains on the top of the crown, heavy dense foam - like a Newtonian fluid - flown down to ground. The effective suppression requires that the foam need to be - more or less - homogenous at all crosssection of the crown. Naturally the crown structure is not ideal thus the foam homogenate can't also be ideal. Probably there is no technology to create an ideal foam homogenate at all cross-section of the crown however the technology to improve it will result higher foam effectiveness.
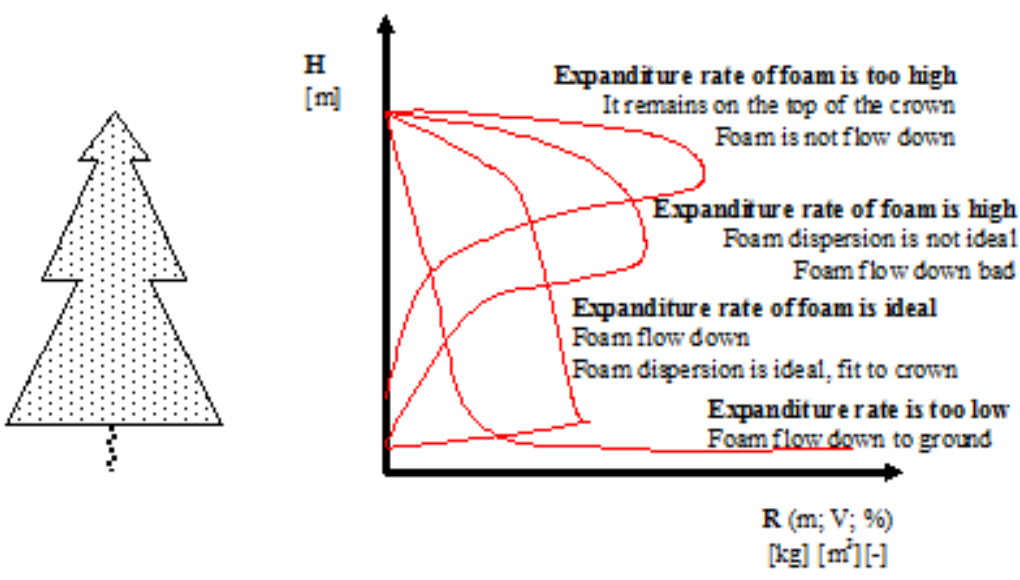

Figure 7. Foams blanket depending on expanditure rate

\section{Basic requirements of foam for effective suppression:}

1. Expanditure rate of foam must be such quality it ensures both the cross flown the canopy and its remaining on twig surface to cover it.

2. The foam weight on the unit surface must be such quantity it ensures to stop fire propagation.

3. The foam structure must be such quality it ensures the minimum water drain and long term stability.

\section{Summarizing the problems regarding using foam:}

1. The foam we need is of homogenous quality. Its density is suitable to maintain its insulation effect yet it can flow down from the crown and provide protection for the required time.

2. The foams designed specially for fighting forest fire meet the condition of remaining on the surface for the required time based on author's assumptions and the information provided by the manufacturers.

3. The current transport methods and means can only partially meet the condition of homogenous quality. It reduces the extinguishing capability of foams.

4. The favourable features of foams are present even at lower foam expenditure for a certain period.

5. In the case of low foam expenditure, the foam maintains it fluidity, typical of Newtonian fluids.

Instant foam for fighting forest fire - I4F technology - is able to ensure that the quality of foam structure is enough homogeneous therefore the losses caused by the different expanditure rates can be reduced and minimized.

\section{Summarizing - concept of adaptation Foam Fatal technology}

Based on the R-20F method foam has an extra extinguishing effect caused by the isolation effect; total suppression effect of foam is - averagely - twice higher than just the quantity of water that foam 
contains (Restas, 2012). Other side, based on the R-10A method the foam remains on canopy 3 times more weight than just pure water (Restas, 2014). Above extra effects can give 6 times more effectiveness than just pure water per unit surface. It means new technology is able to protect the unit surface of vegetation against 6 times higher heat radiation of fire.

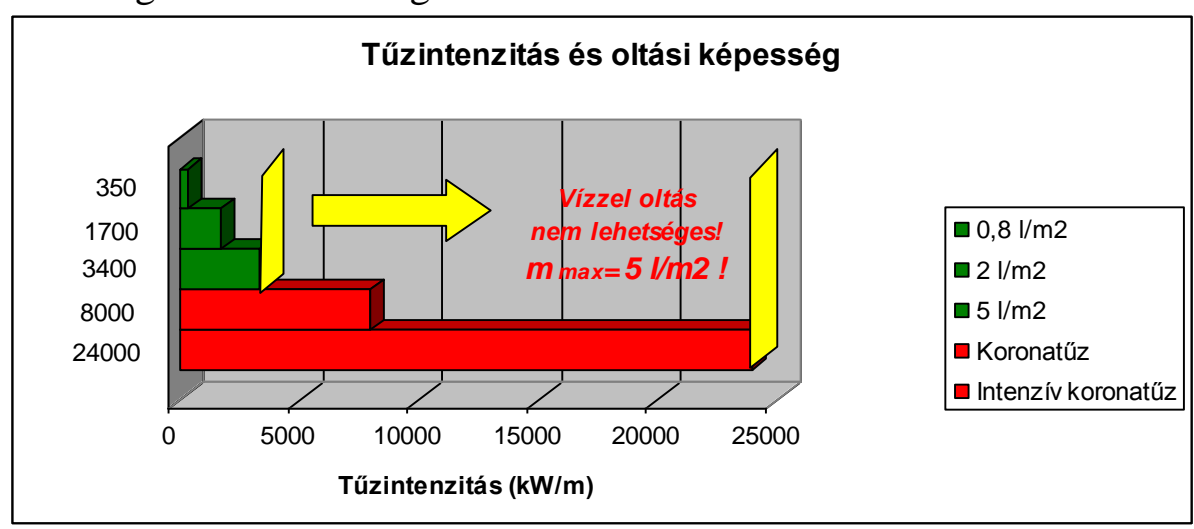

Figure 8. Capability of water and fire intensity. Above $3400 \mathrm{~kW} / \mathrm{m}$ fire intensity water is not effective (red tubs)

The maximum amount of water remains on canopy surface is about $51 / \mathrm{m}^{2}$; it is enough to suppress fires no more than with about $3400 \mathrm{~kW} / \mathrm{m}$ intensity; it means both the effectiveness (capability) and also the barriers of pure water. However in case of canopy fire we can face about $8000 \mathrm{~kW} / \mathrm{m}$, in extra situation to about $24000 \mathrm{~kW} / \mathrm{m}$ fire intensity. Logically follows that using water traditionally is objectively can't be effective in case of canopy fire. Based on the above it also follows that using new technology the extinguishing capability of foam theoretically can extend even to 6 times higher fire intensity - it can be above $20000 \mathrm{~kW} / \mathrm{m}$ - similar to water capability. It means using new technology canopy fires can be supressed that was unable by traditional solution. The above clearly shows the benefits of new technology, which can be supplemented with the comparison of losses.

Table 1-Losses depending on technology

\begin{tabular}{|c|c|c|}
\hline Losses & On-board tank & New technology \\
\hline Loss caused by inhomogeneity & $30 \%$ & $0 \%$ \\
\hline Loss caused by technology & $0 \%$ & $15 \%$ \\
\hline
\end{tabular}

The basic difference between the two technologies can be found in the quality of the foam, which can be demonstrated by inhomogeneity. With the application of new technology the losses are reduced by half.

Extinguishment with instant foam is not new. It is present in hand portable extinguishers, and in petroleum industry at storage tanks as a Hungarian patent. It should be noted that author does not differentiate between instant foam and compressed air foam system (CAFS) regarding the extinguishing capability.

Tank must to be filled about of 4/5 part with water, then add the required amount of foam-forming agent $(0.1-6 \%)$. After that, with the help of a special pump we add gas to the solution until the pressure reaches the suitable value. Practically, the instant foam is ready. The extinguishment starts with the wide opening of the valve of the container. Within an instant, the solution is able to leave the container through the pipeline. As a result, the pressure suddenly and drastically drops which causes 
the solution to become foam. The continual release of gas results in the slow decrease in pressure within the container, which enables the continual and quick release of the liquid and the instant foam. The special hose at the end of the pipeline the homogenous instant foam can reach long distances similarly to water jet.

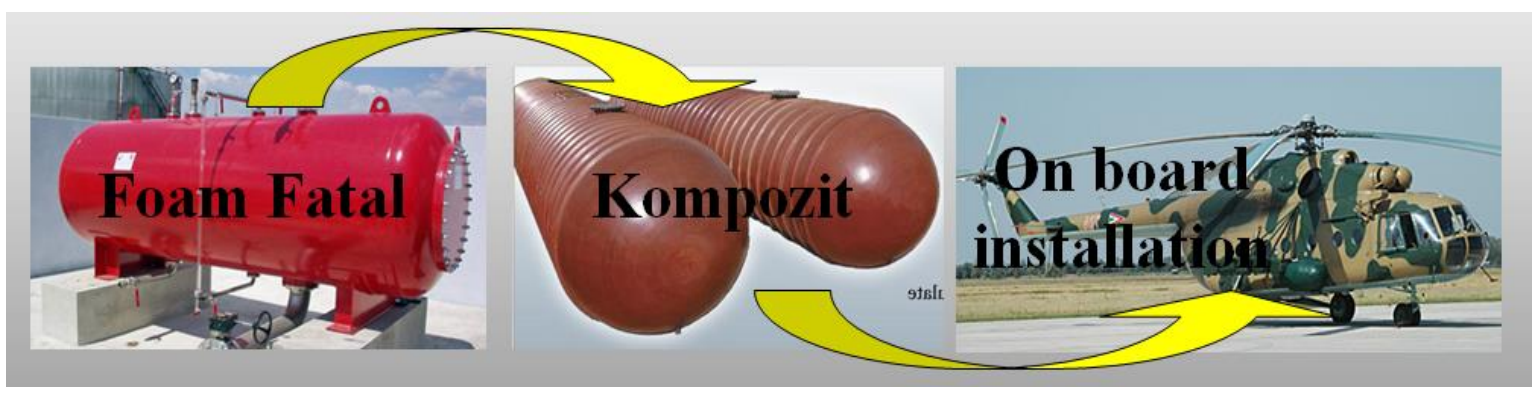

Figure 9. Foam Fatal tank made of composite and install on helicopter board

In order to install the system on board making composite tank instead of meatal one is required. It maximizes the useful part of the loading capacity and makes aerial firefighting more cost effective solution. Author plans to finish tests in 2015.

\section{References}

Csontos P.: Feketefenyveseink kutatása (Research for pine forests in Hungary), MTA-ELTE Elméleti Biológiai és Ökológiai Kutatócsoport, Budapest, 2007

Delforge, P.: Guide d'emploi des moyens aeriens en feux de forets (Handbook for aerial firefighting) Minister de L'Interieur, Paris, France, 2001

Georges, W. C.: Fire retardant ground distribution Patterns from CL-215 air Tanker, USDA Forest service - Research note, INT-165. United States, 1975

Hardy, C.: Chemicals for Forest Fire Fighting, Study, NFPA, National Fire Protection Association, Boston, United States, 1985

Imreh, L., Blaskovits, Zs., Restas, A.: Új módszerek a légi tủzoltásban (New systems in aerial firefighting), Repüléstudományi közlemények, 2009 (2) pp. 1-5, Szolnok, Hungary, HU ISSN 1789-770X

Jambrik, R.: Légi támogatás nélkül nehéz lett volna (It is difficult without aerial support), Vedelem, XIV. (6), pp. 51 - 53, Budapest, Hungary, 2007, ISSN: 1218-2958

Nagy D.: A közvetlen taktika korlátainak fizikai/égéselméleti háttere (Physics backgrounds of fire hindering direct firefighting tactics); Vedelem, XIV 2007 (6), Budapest, Hungary, ISSN: 12182958

Restas, A.: R-20F Method: An approach for measuring the isolation effect of foams used fighting forest fires, Academic and Applied Research in Military Science 11: (2) pp. 233-247. 2012

Restas, A.: I4F technology, Manuscript, R-Fire Ltd, Szendro, Hungary, 2013

Restas, A.: Suppression capability of foams used fighting against forest fires with the test of weight rate remained on the crown surface R-10A Method - weight effectiveness experiment; Manuscript, under publishing, $7^{\text {th }}$ ICFFR, Coimbra, Portugal, 2014

Szabo, G.: Erdőtűz (Forest fire), Study, 1994. http://speed.eik.bme.hu/ gergo/html, downloaded: 2011.05.10. 